\title{
Back to Fukushima: \\ Perceptions and effects of an immersive journalism story
}

\author{
Jorge Vázquez-Herrero; Esa Sirkkunen
}

Nota: Este artículo se puede leer en español en:

https://revista.profesionaldelainformacion.com/index.php/EPI/article/view/86622

How to cite this article:

Vázquez-Herrero, Jorge; Sirkkunen, Esa (2022). "Back to Fukushima: Perceptions and effects of an immersive journalism story". Profesional de la información, v. 31, n. 1, e310108.

https://doi.org/10.3145/epi.2022.ene.08

Manuscript received on July $29^{\text {th }} 2021$

Accepted on November $10^{\text {th }} 2021$

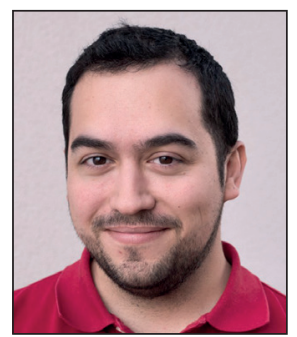

\author{
Jorge Vázquez-Herrero \\ https://orcid.org/0000-0002-9081-3018 \\ Universidade de Santiago de Compostela \\ Facultade de Ciencias da Comunicación \\ Avenida de Castelao, $\mathrm{s} / \mathrm{n}$ \\ 15782 Santiago de Compostela, Spain \\ jorge.vazquez@usc.es
}

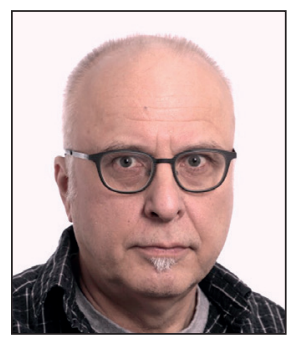

\section{Esa Sirkkunen}

https://orcid.org/0000-0003-1243-1740

Tampere University

Faculty of Information Technology and

Communication Sciences

Kalevantie, 4. 33100 Tampere, Finland

esa.sirkkunen@tuni.fi

\begin{abstract}
News media organizations have been experimenting with immersive journalism formats in recent years. The search for new ways to tell stories is driven by technology and has given rise to new -and not so new- forms of expression. The initial enthusiasm has dissipated over the years, so the uncertainty of the future of immersive journalism justifies the study of the most potential ways of using this technology in journalism. This research was carried out in Finland and Spain, and it is based on a textual narrative analysis and a reception study comparing the online article and 360 video versions of the report Fukushima: Contaminated Lives from El país. The results identify the affordances of both formats and confirm that immersive journalism has the capacity to generate a greater emotional effect based on a greater perception of presence, realism and involvement, also having a positive impact on increasing interest and changing opinions on related topics. The narration of online article seems to work better only if there is large amount of information that has to be understood and contextualized. However, authors claim that, instead of an essential break, there are similarities between both formats, which are situated on the same continuum of emotionality and rationality. These findings also indicate that immersive storytelling can be an important part of the emotional or affective turn in contemporary journalism. The sensation of presence and empathy towards distant and complex realities emerge as the main distinguishing values of the kind of immersive journalism that Fukushima: Contaminated lives represents.
\end{abstract}

\section{Keywords}

Immersive journalism; 360 video; Virtual reality; News media; Immersion; Presence; Empathy; Reception; Experience; Narration; Metaverse.

\section{Funding}

This work was developed within the research projects Emores (Emotions and responsibility in immersive journalism) (Comet Research Centre, Tampere University) and User experience in immersive journalism, supported by Fundación Banco Sabadell (Research Grants 2018). 


\section{Introduction}

The affordances of immersive technologies have affected journalistic storytelling. The experiments with immersive journalism carried out by various media companies have allowed users to get closer to faraway places and stories, making them feel like they are affectively involved 'within the scene'. Major news organisations have produced immersive projects driven by curiosity and a desire to explore new methods of audience engagement (Watson, 2017). The first wave of immersive journalism occurred within a stage of narrative and technological innovation and the investment of media such as the New York Times, Euronews, British Broadcasting Corporation, The guardian and RTVE, among others, from 2015 to 2017. The initial enthusiasm has dissipated over the years, both in Spain (Pérez-Seijo, 2021; Sidorenko-Bautista; Herranz-de-la-Casa; Molina-Díez, 2020) and in the rest of the world (Sirkkunen et al., 2020). The uncertainty of the future of immersive journalism motivates us to study further what are the most potential ways of using this technology in the making of journalism, at a time of uncertainty, challenges and opportunities for journalism in the face of the announcement of the forthcoming metaverse (Owen, 2016; Kang et al., 2019).

Immersive journalism has been defined as creating the sense of being there (De-la-Peña et al., 2010). Lately, some scholars have defined it as a part of the more general emotional turn in journalism (Beckett; Deuze, 2016; Uskali; Ikonen, 2021). The emphasis in journalism on raising affect among the audience has led to the development of a new kind of research concerning this emotional turn (Wahl-Jorgensen, 2020). Lecheler (2020) has pointed out that the evidence of audience perceptions is vital to understanding the development of emotion-driven journalism more profoundly.

Fukushima: Contaminated lives (Fukushima, vidas contaminadas) is a report created by El país in 2016 after the catastrophe that caused the evacuation of the Fukushima area of Japan, which is available in Spanish and English. Through a 360 o video and an article based on text and pictures, users of El país could experience and make sense of the story narrated through two different technologies that were complementary and independent.

https://english.elpais.com/elpais/2016/05/02/inenglish/1462201618_695572.html

Following Barreda-Ángeles, the immersive format is used

"to narrate events in which the spatial environment is key to better understanding the information or to sensitize the user, and of which the user is unlikely to have a first-hand experience" (Barreda-Ángeles, 2018, p. 1117).

This case has been previously analysed, but only by examining the 360 video. Benítez-de-Gracia and Herrera-Damas (2018) draw attention to formal aspects; also Pérez-Seijo, López-García and Campos-Freire (2018) do it in their study on immersive journalism in El país and indicate that it is the most representative piece of the immersive narratives explored by this reference media in Spain.

Until now, the study of immersive journalism has been largely carried out via formal analysis and there are also studies that evaluate the effect of immersive formats in terms of various variables such as technologies and devices. Our research aims to fill a gap in the analysis of narration and perception in immersive journalistic projects with a multiplatform approach; in this case, the online article and 360 video.

Based on mixed-method research, this paper combines textual narrative analysis and an empirical reception study. First, in the textual analysis we explore how 2D online journalism and 360 video journalism build their emotional effects, journalistic credibility, and connection to the audience. This method allows us to identify the narrative strategies used in the online article and the $360^{\circ}$ format of Fukushima: Contaminated lives and study the similarities and differences in the audience reception of both forms of narration. With this comparison we wish to emphasise that the 2D content also builds emotional bonds with the audience but uses different means to achieve this end. 3D is often described through its technical affordances as an essential break in the development of journalistic narration. However, we claim that instead of an essential break there are also similarities between these two genres, following the more general narrative conventions of journalism.

For the audience reception study, a laboratory situation was set up involving 28 students from Finland and Spain from two universities involved in research and teaching of immersive journalism. They viewed the article online on a computer and also experienced it in immersive format using Oculus Go devices. An experimental group and a control group were defined according to the format they first saw for the evaluation of the effect. Both before and after the experiences, participants were asked to fill in questionnaires. This method was used in order to discover how format influences the users' interests in related topics before and after viewing. Three fundamental parameters of immersive narration -presence, realism and involvement- were evaluated in detail to explore the possible reception differences between the online article and the 360 o video. In addition, the questionnaire data allowed the researchers to identify the main positive and negative features of these two technologies from the users' experience.

In short, the study presents the contributions of two different technologies and formats -two-dimensional online journalism and immersive 360 o video journalism - on journalistic storytelling. The paper discusses the effects on interest and the perception of immersion, as well as the factors that affect users' experiences. Overall, the findings seem to indicate that the 360 o video contributes positively to users' general interest in the story, adding affective factors, like a sense of presence, realism and immersion, to users' experiences. The textual narration seems to work better only if there is large amount of information that must be understood and contextualized. 


\section{Background}

After the huge media attention given to virtual reality at the end of 2015 and into 2016, interests and expectations have arisen and, in this transition from technological fad to the creation and production of appropriate content, the experience of the users must be studied. The application of immersive narratives in journalism has led to the publication of several reports (Marconi; Nakagawa, 2016; Watson, 2017) that point to their potential value in the approach to information.

Immersive journalism has been defined as

"the production of news in a form in which people can gain first-person experiences of the events or situation described in news stories" (De-la-Peña et al., 2010, p. 291),

"a narrative form that seeks immersion through interactive and visual techniques consisting of fostering the active role of the user in the story and a sensory experience of space exploration" (Domínguez-Martín, 2015, p. 420),

"a new way of creating journalistic representations that can be interpreted, experienced, and responded to as being real" (Sirkkunen; Uskali, 2019, p. 2801).

In the different conceptions, the user has a central role.

Journalism is permanently in a state of change (Franklin, 2016), assuming that innovation is the answer to technological and economic uncertainty (Pavlik, 2013). Telling a story is inherent to journalism and, in stages such as the narrative movement of the 1960s, New Journalism, and a response to infotainment, we have seen the journalist become a part of what the story being told (Neveu, 2014; Jones, 2017):

"They demonstrated an involvement in features and a conflicting storytelling style" (Jones, 2017, p. 174).

Thus, immersion is not something radically new, but it is a sign that digital journalism shapes and is shaped at the same time by technologies (Steensen et al., 2019).

The concept of virtual reality and immersion is also found in literature and other arts that seek to immerse the user in a represented world, although through language a greater imagination is required to produce an image in the readers' mind (Ryan, 2001). Narrative immersion, in both fiction and factual stories, depends on a number of factors including descriptions rich in sensory, spatial and temporal information, character focalization, and the creation of empathy (Allan, 2019). Narrative analysis of journalism has been developed from literary studies, based on structuralist tradition. In journalism studies this method has been used to explore the textual narration of different journalistic genres, like news (Bird; Dardenne, 1988) or reportages (Berning, 2011).

For De-Bruin et al. (2020), the four main elements of immersive journalism are:

1) immersive technologies;

2) immersive features in the narrative;

3) interaction or agency possibilities for the user; and

4) the outcome of sense of presence and emotional engagement.

Immersive technologies range from 360 video to virtual, augmented and mixed reality. The concept of extended realities groups all these dimensions, which implies a significant change in the traditional communication model (Paíno-Ambrosio; Rodríguez-Fidalgo, 2019b). The consumption can be carried out through a mobile device, by navigation with a mouse, Cardboard glasses or other head-mounted display devices that are more sophisticated and built for this purpose. Due to the relevance of the technological aspect in consumption, it is an area where we find previous studies on the experience of immersive journalism, such as the comparison of 360 video consumption in diverse devices (Van-Damme et al., 2019) or between different formats such as online articles, podcasts and 360 videos (Kelling et al., 2019) or text, 2D videos and 3D VR experiences (Steinfeld, 2020). The results indicate the positive effects of immersive devices and formats, although as already pointed out, immersion is not exclusive to these formats.

Immersive journalism challenges narrative conventions (Domínguez-Martín, 2017) while adapting classic elements of the narrative (Jacobson; Marino; Gutsche, 2016; Paíno-Ambrosio; Rodríguez-Fidalgo, 2019a): thematics, dramatic tension, description of the place or realism. The presence of the journalist and the sources also intervenes in the perception of being there, as does the exposure in first or third person and the point of view of the user. The immersive rhetoric involves elements from other formats - cinema, video games, etc. - such as movement by continuity, constant ambient sound, narrative experience or personification (Domínguez-Martín, 2015). A key aspect, from the definition of immersive journalism, is space, which has a direct effect on what is experienced and how it is experienced on three levels: space simulating the characters' emotional reality, places as narrative strategies, and dialogue with space (Kukkakorpi; Pantti, 2020). In this sense, Colussi and Reis (2020) point out that the most frequent immersion in the media is of the spatial type -presence, simulation, plausibility, 'being there'- as opposed to the more advanced and interac-

The initial enthusiasm on immersive journalism has dissipated over the years 
As a consequence of the use of technological artifacts and narrative resources, immersive journalism promotes interaction and agency, to make the user feel part of news events. In short, it seeks the sensation of presence and an emotional engagement that culminates in the experience:

"Immersive journalism is often called an 'empathy machine' proved to be extremely effective in causing strong emotions among its users" (Gynnild et al., 2020, p. 1).

Therefore, the experience in this type of story is being analysed from different perspectives and multiple case studies. Shin and Biocca (2018) studied it according to the level of immersion of the product and the personality traits of the audience, confirming the relationship between immersion with empathy and embodiment. Nielsen and Sheets (2019) applied uses and gratifications theory to identify what immersive journalism brings to the user and what its strengths are with respect to traditional journalism, highlighting that it can add value to many journalistic productions. Spiller and colleagues (2019) proved with an experiment that empathy is greater after exposure to virtual reality, in a case applied to an NGO. Wu et al. (2021) compared VR news with and without interaction, showing that interactive pieces offer improved media effects and user experience.

In immersive journalism, the user puts themselves in the reporter's place to become immersed in the scene and decide -to a certain extent- where to look and what to listen for. The change of paradigm is significant: first person, a feeling of being there, the predominance of the spatial dimension, emotional turn -"freedom and autonomy in their own news story" (Jones, 2017, p. 182).

However, the disruptions presented by immersive journalism expose it to debate, especially concerning its ethical aspects (Sánchez-Laws, 2020).

\section{Methods}

Several recent publications (Shin; Biocca, 2018; Nielsen; Sheets, 2019; Van-Damme et al., 2019) require our research to be more focused and address a specific and unexplored area. The object of our study is focused on the narrative strategies and user experiences in immersive journalism with a comparative approach between the two formats of Fukushima: Contaminated lives. Specifically, we wanted to answer the following questions about the possibilities and contributions of the different media and the purpose of immersive formats in journalism:

RQ1. What are the narrative strategies used in the online article and the $360^{\circ}$ format of Fukushima: Contaminated lives?

RQ2. How do both formats influence the perception of presence, realism and involvement?

RQ3. How do these formats improve or reduce interest in the topic?

Based on these research questions, we defined three hypotheses to be tested in the research:

H1. The immersive format favours the perception of presence, realism and involvement.

H2. The immersive format encourages interest in the subject matter and the user's commitment to it.

H3. The immersive format is more attractive and has a greater emotional impact, while the article is the preferred option for obtaining information.

Firstly, a textual narrative analysis of the online version -in English- was carried out to answer the first research question. The story can be found on the site of El país semanal. The story is written by Daniel Verdú, translated by Heather Galloway, and published on 2 May 2016.

Narrative analysis

"include, but [is] not limited to, how the story is structured, what functions the story serves, what is the substance of the story, and how the story is performed" (Sahlstein; Baker, 2017, p. 1069).

This analysis is based on the researchers close reading of the story regarding textual and audio-visual aspects (Table 1). We understand both formats as results of a journalistic work process which creates meanings to the story according to certain generic features of journalism. We focused on the following features of the story:

- the construction of sense of presence;

- how the reader is involved around the topic;

- the construction of narration;

- the construction of realism. 
Table 1. Narrative analysis parameters

\begin{tabular}{|l|l|}
\hline Narrative voice & Narrator, verb tenses \\
\hline Structure & Organisation of the story \\
\hline Characters/interviewees & Description, position to camera, statements \\
\hline Environment & Description, representation, observation \\
\hline Sources and background & Sources, direct quotations, complementary information, statistics, references to history \\
\hline Style & Resources to generate emotion, empathy and connection \\
\hline Audio-visual level & Pictures, video, audio, subtitles, infographics, rhythm \\
\hline $360^{\circ}$ features & Interaction, role of the user, position within the scene \\
\hline
\end{tabular}

To address the second and third research questions, an audience reception study was conducted. The product under study, Fukushima: Contaminated lives, was provided to participants in both versions: as an online article on a desktop computer and as a 360응 video in Oculus Go. As shown in Figure 1, the experimental group first viewed the immersive format and answered the perception questionnaire. The control group first read the online article and answered the questionnaire. Both groups then view the other format and answer a final comparative and

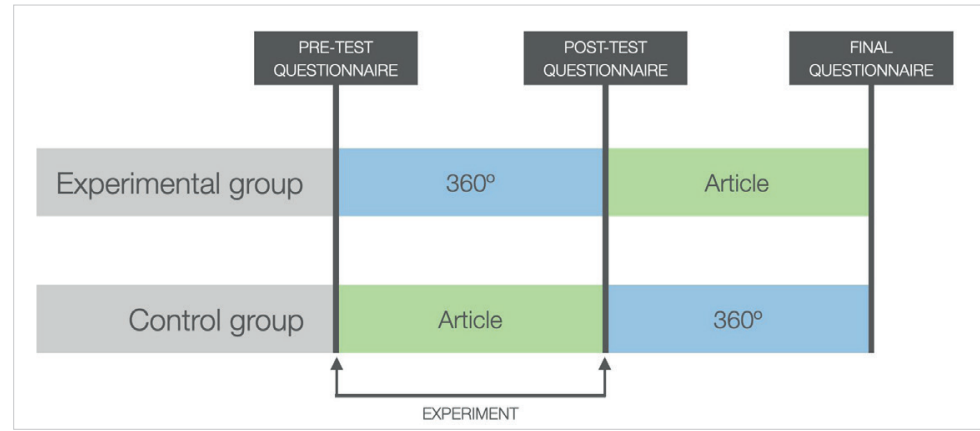

Figure 1. Experimental design open-ended questionnaire. Data was collected through online questionnaires: one before viewing, one after each of the formats, and a final comparative one; in addition, direct observation notes were taken during the experience, which was carried out under laboratory conditions.

The sample was characterized by its international and inter-institutional composition. The 28 Finnish and Spanish participants are students and early-career scholars from the Tampere University and the University of Santiago de Compostela. Both institutions have a noteworthy background in the development of research on immersive journalism. The Tampere University has developed this line of research with several projects (Virjox; Emores) and immersive journalism is also an important part of journalism courses on several levels. The University of Santiago de Compostela also incorporates this perspective in the most recent projects (Uses and informative preferences in the new media map in Spain: journalism models for mobile devices; Digital native media in Spain: storytelling formats and mobile strategy) and has transferred this knowledge to the curricula, being a differentiating aspect in the university offer in Spain (Ufarte-Ruiz; Calvo-Rubio; Murcia-Verdú, 2020).

The limitation of resources affects the size of the sample and its diversity, so priority was given to a group with similar characteristics: students and researchers in communication and journalism, aged between 18 and 35. This decision was also based on the innovative nature of immersive journalism and the necessary critical analysis due to the debates it opens, with the perspective of future journalists and communicators being of particular interest. ${ }^{1}$

For the construction of the questionnaires, reference was made to previous studies, as shown in the following tables 2 , 3 and 4 . A Likert scale from 1 to 7 was used for the quantitative variables. Three fundamental parameters of immersive narration -presence, realism and involvement- were evaluated in detail to explore the possible reception differences between the online article and the 360 o video. Another important issue was to identify the main positive and negative values of these two technologies from the users' experience, as well as their preferences and limitations for consumption.

Table 2. Pre-test questionnaire

\begin{tabular}{|l|l|}
\hline Demographics & ID, age, gender, nationality, occupation, field of studies \\
\hline Previous knowledge of the product & yes/no \\
\hline Previous experience & $360^{\circ}$ video or VR in: laptop, smartphone, Cardboard, headset \\
\hline Attitudes towards technology & Ethical issues in journalism \\
\hline Interests & $\begin{array}{l}\text { Media innovation, documentary and reportage, technology, journalism, videogames, environmen- } \\
\text { tal issues, nuclear energy issues, climate change }\end{array}$ \\
\hline Concerns & Natural disasters, nuclear energy accidents \\
\hline Opinions & Use of nuclear power plants, environmental initiatives \\
\hline
\end{tabular}


Table 3. Post-test questionnaire

\begin{tabular}{|c|c|c|}
\hline \multirow{3}{*}{ Presence } & Being there & Slater and Usoh (1994) \\
\hline & Surrounded & \multirow{2}{*}{ Schubert, Friedman and Regenbrecht (2001) } \\
\hline & Present & \\
\hline \multirow{4}{*}{ Realism } & World as real & Van-Damme et al. (2019) \\
\hline & Similar experience & Shin and Biocca (2018) \\
\hline & Hyper-realistic & Schubert, Friedman and Regenbrecht (2001) \\
\hline & Inconsistencies & Sundar, Kang and Oprean (2017) \\
\hline \multirow{4}{*}{ Involvement } & Be aware of the real world & Witmer and Singer (1998) \\
\hline & Be together & \multirow{3}{*}{ Sundar, Kang and Oprean (2017) } \\
\hline & Be interacting & \\
\hline & Whole attention & \\
\hline Interests & \multicolumn{2}{|c|}{ Environmental issues, nuclear energy issues, climate change } \\
\hline Concerns & \multicolumn{2}{|c|}{ Natural disasters, nuclear energy accidents } \\
\hline Opinions & \multicolumn{2}{|c|}{ Use of nuclear power plants, environmental initiatives } \\
\hline \multirow{4}{*}{ Commitment } & Need to get information & \multirow{4}{*}{ Van-Damme et al. (2019) } \\
\hline & Need to get involved & \\
\hline & Need to encourage people & \\
\hline & Need to discuss & \\
\hline \multirow{3}{*}{ Enjoyment } & Enjoy the story & \multirow{2}{*}{ Sundar, Kang and Oprean (2017) } \\
\hline & Captivating & \\
\hline & Boring & \\
\hline \multirow{3}{*}{ Continuation desire / Deepening } & Continuation desire & Schoenau-Fog (2011) \\
\hline & \multicolumn{2}{|l|}{ Deepening } \\
\hline & \multicolumn{2}{|l|}{ Acquired knowledge } \\
\hline \multirow{3}{*}{ Deseo de continuar y profundización } & Deseo de continuar & Schoenau-Fog (2011) \\
\hline & \multicolumn{2}{|l|}{ Profundización } \\
\hline & \multicolumn{2}{|l|}{ Conocimiento adquirido } \\
\hline
\end{tabular}

Quantitative variables were studied with SPSS software to identify the main descriptive statistics and significant differences by format -a $t$-test for variables with normal distribution, and Mann-Whitney $U$ test and $Z$ for variables with non-normal distribution. With respect to the qualitative variables, NVivo software was used to systematize their analysis, obtaining a precise summary of the most frequent and outstanding ideas in the participants' open responses.

\section{Textual narrative analysis}

\subsection{Online version}

In analysing the online version of Fukushima: Contaminated lives we wanted to know what textual (and visual) strategies were used in narration and how the sense of presence, emotional involvement and realism were created. In this analysis we explored how the narrator was present in the text, how events in the text were arranged as a story and how the characters/interviewees were framed and depicted.

In general, the analysis shows that this text strengthens the role of journalism and journalists as eyewitnesses for their audience (Zelizer, 2007) in various ways. First, we present some examples of how the narration creates the sense of presence in the text. The feeling of being present can be created for example by carefully depicting the habitus of the interviewee and using the present tense as the reader would meet him in real life and real time. An example from the text:

"A slight, reserved man, Kanakura nods and lowers his gaze. Japanese people are not generally given to expressing their feelings, he says, but he is clearly upset as he explains how much he has missed his work and his customers since March 11, 2011." 
Another method of giving a sense of presence is describing the physical details of the environment to the readers to make them feel that they are on the spot making observations.

"To reach Daiichi, you have to protect yourself with rubber boots, gloves and a mask. There is an electric fence that obliges you to enter through a police checkpoint where they can measure radiation levels.

In some houses, the doors have been left ajar, allowing monkeys and wild boar to use them for shelter. Others have their windows broken and the curtains blow desolately through the empty panes. There are plates of food on the tables, piles of hastily discarded clothes in the wardrobes, notes on fridges with lists for a week long gone and family photos in a muddle in open drawers."

In the online version there are eight photos (Table 5) that provide a sense of the place for readers. In general, pictures can be understood as evidence that the journalists have really visited the area and provide some sense of the environment to the reader. All photos strengthen the credibility of the written text and its sense of presence.

Table 5. Pictures in Fukushima: Contaminated lives (online article)

\begin{tabular}{|c|l|l|}
\hline Picture & \multicolumn{1}{|c|}{ Author } & \multicolumn{1}{c|}{ Description } \\
\hline Picture 1 & Javier Tles & A shattered house \\
\hline Picture 2 & Javier Tles & Fukushima City Hall employees take measurements \\
\hline Picture 3 & Alfredo Cáliz & A rusty bus and a pile of radioactive waste in black bags \\
\hline Picture 4 & Javier Tles & Radioactive gauges that the Japanese government has installed on trees in the affected areas \\
\hline Picture 5 & Alfredo Cáliz & Naoto Kan, former Prime Minister, from Greenpeace ship \\
\hline Picture 6 & Javier Tles & A colony of portacabins in Koriyama \\
\hline Picture 7 & Alfredo Cáliz & The interior of a deserted hairdressing salon \\
\hline Picture 8 & Alfredo Cáliz & Toyotaka Kanakura standing on an abandoned street, looking at his old florist's shop \\
\hline
\end{tabular}

Next, we introduce some examples of how the narration builds involvement around the topic of nuclear waste. Involvement is here understood as narration that appeals both on emotional and factual levels to readers. One strategy involves creating empathy by telling moving stories about the sacrifices of the residents and Japanese people in general when it comes to nuclear disasters.

"Two years ago, he had a heart attack and a stroke and it seemed as though the stress and insecurity of his situation was killing him. But in the hospital they found a hole in the frontal lobe of his brain that was producing paralysis down the left side of his body. The doctor said it could have been caused by absorbing cesium over a period of time. 'We kid ourselves about the levels of radiation", says Mr Anzai. 'What's the use of compensation? I've lost everything: my life, my land, my memories... I'm very angry and every time I come here, I go to pieces.'”

The narration also creates involvement by juxtaposing the nuclear bombings in Hiroshima in WW2 and the experiences at that time to the suffering of the Fukushima residents today.

One way of building involvement around the seriousness of the situation in Fukushima was to choose mainly those interviewees that had personal and lived information about the problems still going on in the area. Of the many sources named in the text, only one, the government of Prime Minister Abe, is shown as open to the reopening of nuclear plants in Japan. The rest of the sources express strong doubts about the reopening and the usability of nuclear power in Japan in general in the future. This deliberate bias in terms of sources can be understood as a moral judgement made through the selection of sources rather than an open judgement.

The narration of Fukushima: Contaminated lives builds realism by using conventional journalistic strategies, offering background information, statistics and direct quotations of the interviewees to show that the story is based on facts and

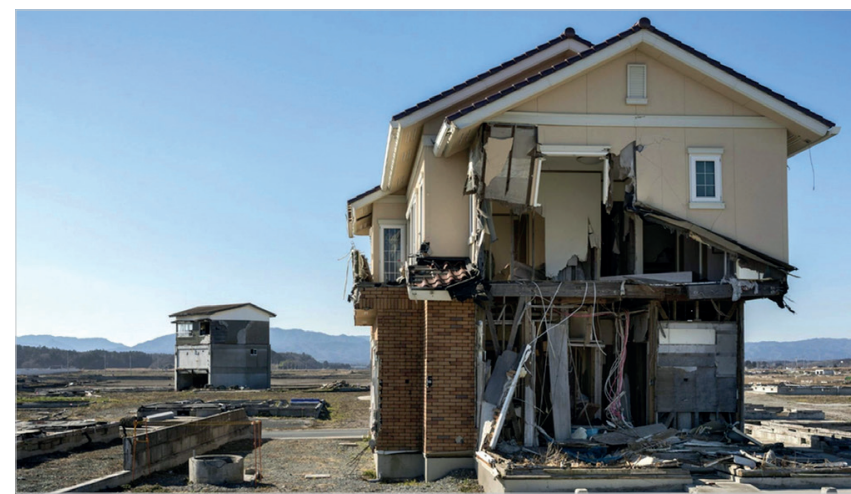

Figure 2. A destroyed house (Javier Tles) https://english.elpais.com/elpais/2016/05/02/inenglish/1462201618_695572. html

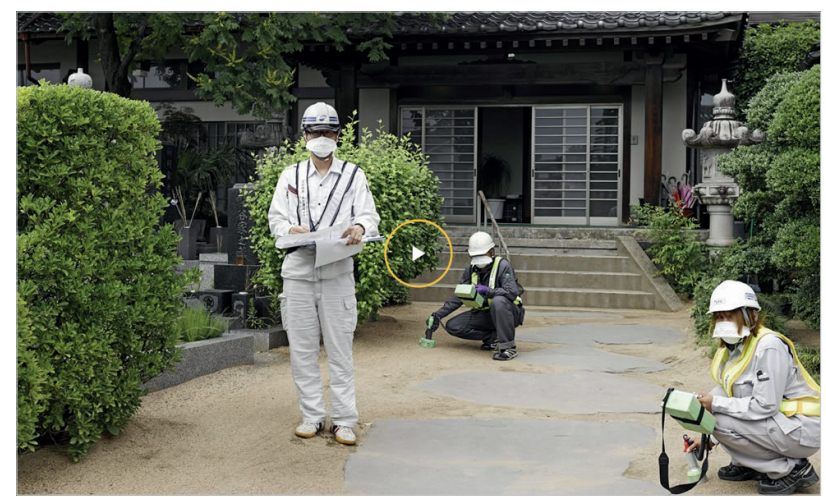

Figure 3. Fukushima City Hall employees doing measurements (Javier Tles) https://english.elpais.com/elpais/2016/05/02/inenglish/1462201618_695572. html 


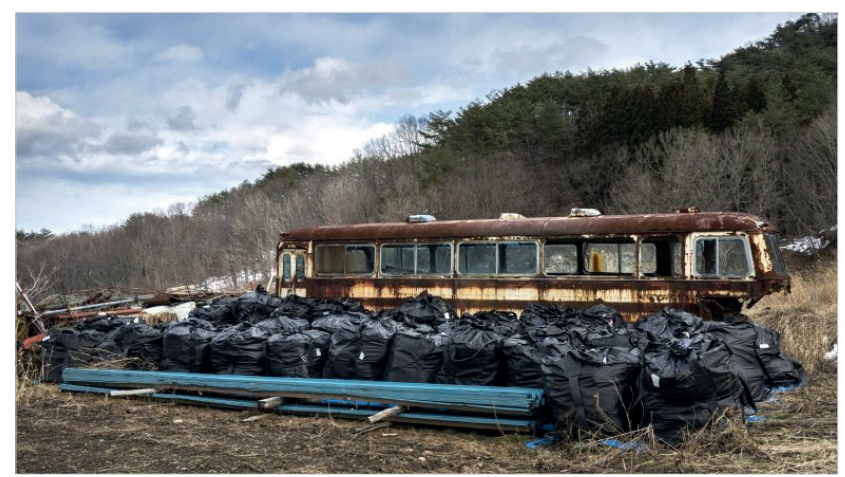

Figure 4. A rusty bus and a pile of radioactive waste in black bags (Alfredo Cáliz) https://english.elpais.com/elpais/2016/05/02/inenglish/1462201618_695572. html

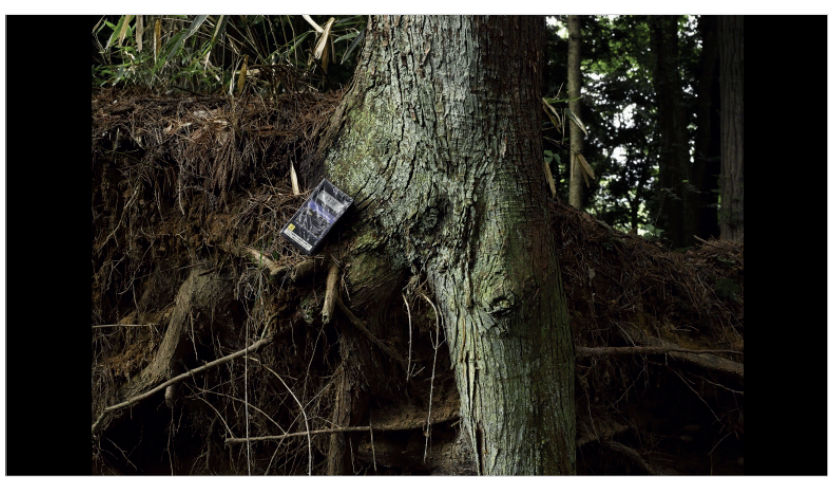

Figure 5. Radioactivity meters that the Japanese government has installed in trees in affected areas (Javier Tles)

https://english.elpais.com/elpais/2016/05/02/inenglish/1462201618_695572. html

real verbal utterances. The omniscient narration, common in news journalism in general, tells the story 'as it happened', not underlining the active role of the journalist in creating the story from facts, field notes and interviews. The omniscience gives the narrator a detached role, orchestrating the elements and not interfering openly with the course of the story in general. One example of the detached narration is how the narrator depicts himself; the name of the journalist is avoided and replaced with the name of the publication. Also, the photos serve to strengthen the impression of realistic narration. The reality in the story seems to unfold by itself.

"Where once there were paddy fields, there are now mountains of black bags waiting to be incinerated in the decontamination depots. They have already disposed of 9.5 million bags but there are still 13 million to go before they will have cleaned up an area twice the size of Madrid. Meanwhile, the lives of the evacuees move slowly forward in the prefabricated houses that line the frontier of the exclusion zone."

The narration of the story uses various strategies to give the impression of presence, strengthen the involvement of readers and give a sense of realism to the story. In this online textual version the omniscient narrator has complete control over the story elements. The narrator builds the story and lets the facts and the voices of the interviewees speak while they remain in the background. As noted earlier, the story combines field observations and interviews with various contextual materials. The story time moves from the present (2016) to the disasters in 2011 and even to WW2 bombings. There are elements of empathy-building for the residents and contextual criticism against the government's plans to open the nuclear plants again. This story can be counted in the genre of journalistic reportage, in which moral claims and conclusions can be made (Berning, 2011). The tone of the story can be described as a cultural critique of Japanese (and Western) consumption. One of the interviewees, professor Takashi Sasaki, states that:

"They say it was an accident. But it's actually the result of having lost the essence of our culture, our contact with nature, our measured approach to work, our ceremonies... We have failed in terms of our education and our traditions. Nowadays, the Japanese gods are convenience and progress. Nuclear energy is a reflection of that and the accident is a direct consequence."

\subsection{0 version}

The ability to create a sense of presence is maybe the main affordance of 360 technology. In Fukushima: Contaminated lives it gives the user a sense of presence in various points of nuclear wasteland, in abandoned homes, shops and in temporary houses built for the victims. Although there is no real interaction with the environment, the possibility to choose where to look adds the feeling of being there. The full audio from the field is mixed with voice-over narration, which occasionally weakens the immersive effect of the spatial audio. The role of the user is more of a passive bystander following the show than an active explorer of the scene.

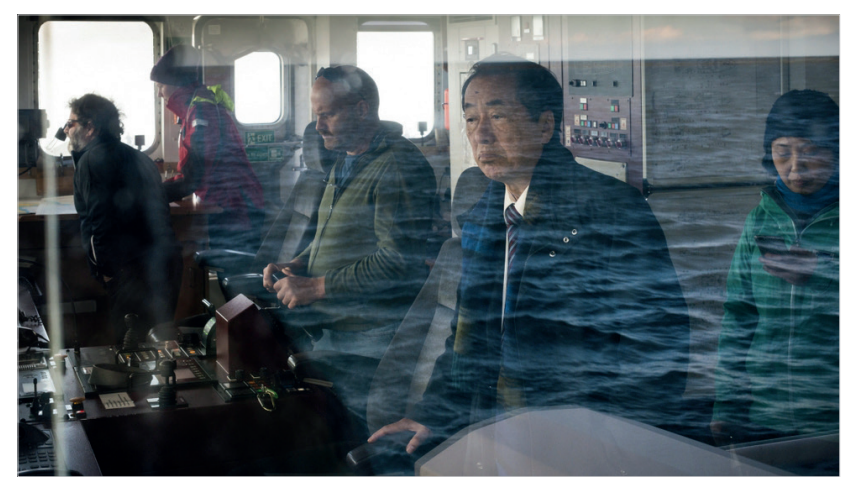

Figure 6. Naoto Kan, former Prime Minister, from the Greenpeace ship (Alfredo Cáliz)

https://english.elpais.com/elpais/2016/05/02/inenglish/1462201618_695572. htm

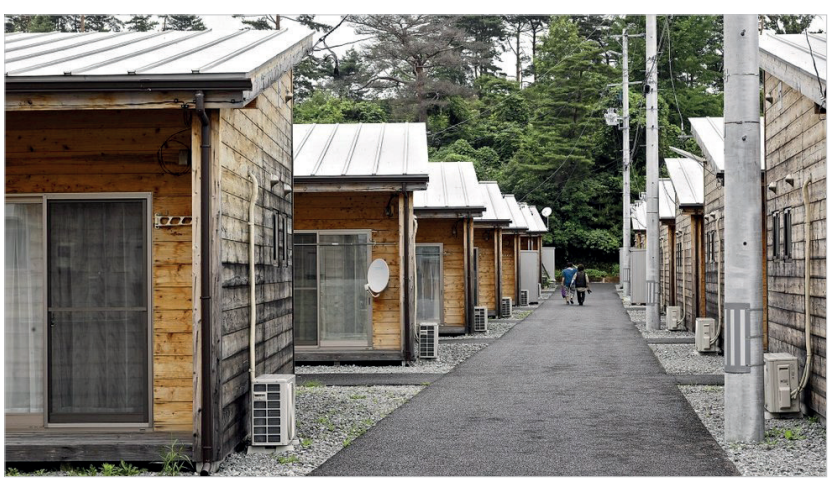

Figure 7. A colony of portacabins in Koriyama (Javier Tles) https://english.elpais.com/elpais/2016/05/02/inenglish/1462201618_695572. html 


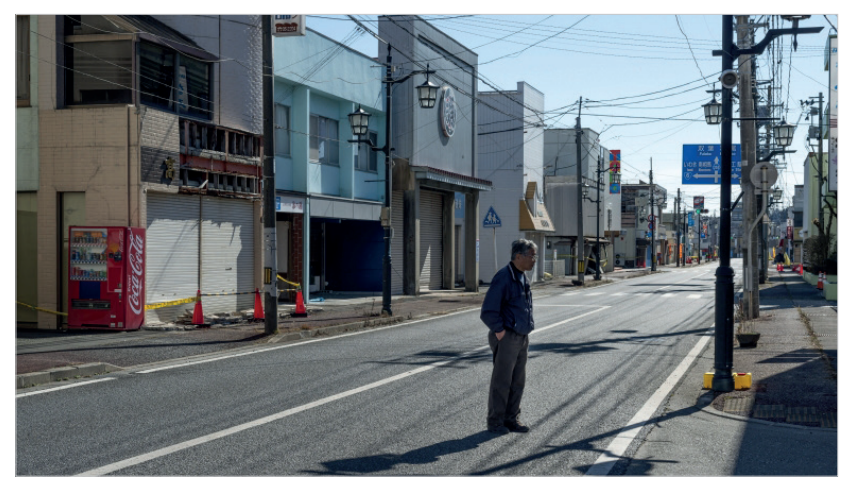

Figure 8. Toyotaka Kanakura standing on an abandoned street, looking at his old flower shop (Alfredo Cáliz) https://english.elpais.com/elpais/2016/05/02/inenglish/1462201618_695572. html html

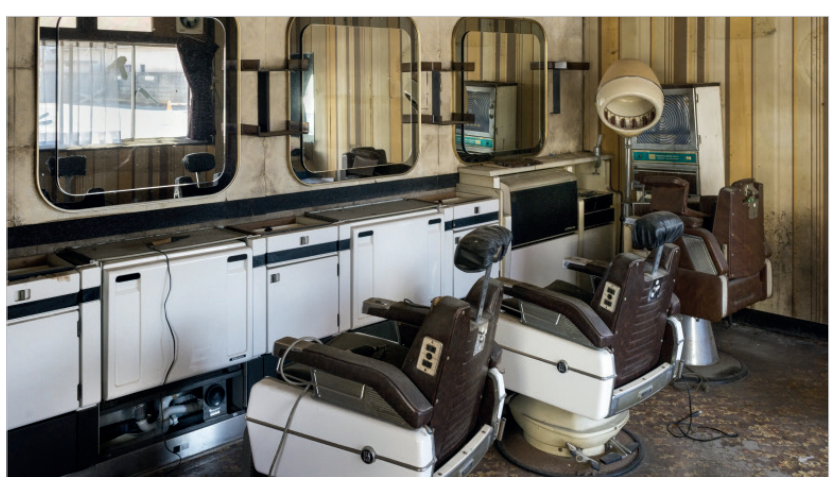

Figure 9. The interior of a deserted barbershop (Alfredo Cáliz) https://english.elpais.com/elpais/2016/05/02/inenglish/1462201618_695572.

The user is being involved, giving them a sense of presence by looking at the abandoned landscape, listening to the stories of the residents and getting an idea of the scale of the disaster described by the voice-over. The sorrow and pain that the people express when being interviewed in their abandoned homes becomes touching while looking at and listening to them at close distance. The user also obtains factual information about the history and present state of the disaster and the cleaning up process through the voice-over narration so one can say that there is lot of factual material for the users to digest.

Concerning the construction of narration, the $360^{\circ}$ footage begins with the abandoned city of Namie and ends on the deck of the Greenpeace ship on which the former Prime Minister of Japan admits the mistakes that the Japanese officials made before and after the catastrophe. The 360 o version broadly follows the narrative of the online version with the same interviewees but with shorter quotes and less background information. The only new interviewee compared to the online version is Naoto Matsumura, a builder who has been living on the contaminated area for years, taking care of abandoned animals. The narrative voice is mostly neutral and omniscient, and the El pais journalist is not visible. However, the storyline and dramatic scenes work as moral statements against nuclear power, concretely showing the scale of the disaster. There is a voice-over narration explaining the backgrounds of the scenes, which gives information and keeps the story moving. The ongoing narration does not give the user too much time to explore the 360 o panoramas in peace, while the interviewees and animations capture the viewer's attention. The journalistic narration builds its credibility not just on the illusion of the user being on the spot but also by providing a lot of factual information and using narrative conventions of TV-reporting like voice-overs, animations and interviews with subtitles. What is not rare, since we have found conventions of film and television documentaries in our content analysis of the early 360 o video news and documentaries (Sirkkunen et al., 2020).

Construction of realism is based on the illusion of being there caused by the 360 o video and the factual content. However, the subtitles that float around and the animated maps occasionally break the illusion of the real environment. The realism is here constructed not only with sensory observations and emotionally strong footage -it is also based on the stories of the residents, interviews with experts, and the general facts of the Fukushima accident provided through animations.

To conclude, we have shown with this analysis how the narrative voice of the El pais 360 video not only creates affects but rather builds an interactive process between emotional and more rational evaluation in the process of reception by users. The 360 o video version of Fukushima: Contaminated lives does not just construct empathy for the victims of the disaster but provides context for the user to understand the reasons behind this disaster.

Comparing both formats, we want to emphasise that there is no clear-cut break between $2 \mathrm{D}$ and $3 \mathrm{D}$ journalism $-2 \mathrm{D}$ being rational and unemotional, and $3 \mathrm{D}$ affective and irrational. We situate both formats on the same continuum of emotionality and rationality. We discuss our findings in more detail in the Conclusions section. Next, we move to the reception study to explore what kind of affects and meanings the participants found in these two formats.

\section{Reception study}

The research allows us to obtain results and learning both from the methodological perspective and from the effects on the user experience. On the one hand, it allows us to contrast a series of variables and scales to approach the knowledge of the reception in narrative products of immersive character and, specifically, in the journalistic activity. On the other hand, the main objective has been to find out what the effects are and to what extent they appear.

\subsection{Demographics}

The 28 participants came from Spain (14) and Finland (14), aged between 20 and 35 years old (average: 24.6), and were students and researchers in the area of Journalism $(71.4 \%)$ and Communication $(28.6 \%)$, from undergraduate to postdoctoral. Regarding gender, $53.6 \%$ were women, $42.9 \%$ men and $3.6 \%$ chosen not to answer. In $78.6 \%$ of the cases, their dedication to their studies was exclusive, without exercising any other activity. 


\subsection{Consumption}

Regarding the frequency with which they consume a series of formats, a low penetration of the most advanced devices for virtual reality consumption (head-mounted display or headset) was observed. Specifically, $60.7 \%$ of participants had never used a device such as Oculus, HTC Vive or Samsung Gear, while $82.1 \%$ had never used a Cardboard viewer with their smartphone. Thus, we see that the most common consumption of immersive products is carried out through a laptop or smartphone. Among those who said they consumed immersive content more than once a year, laptop (50.0\%) and smartphone (50.0\%) were also more popular than Cardboard (7.1\%) or headsets (10.7\%). Thus, we can infer that these technologies have not yet managed to penetrate and install themselves in regular consumer routines.

\subsection{Evolution of interests and opinions}

Of the six items related to interests and opinions on the subject of the report, five show statistically significant differences between the time before the test and the time after viewing the immersive format. With the exception of 'concern about natural disasters', which increased after both formats with no statistically significant differences from the pre-test questionnaire, items shown in Table 6 point to the positive effect of the immersive format on interests and changes of opinion.

Table 6. Comparison of interests and opinions

\begin{tabular}{|c|c|c|c|}
\hline & Before viewing & $\begin{array}{l}\text { After immersive } \\
\text { format }\end{array}$ & Compared means \\
\hline Interest in environmental issues & $M_{1}=5.21$ & $M_{2}=5.75$ & $Z=-2.543 *$ \\
\hline Interest in nuclear energy issues & $M_{1}=4.04$ & $M_{2}=4.96$ & $t=-3.099 *$ \\
\hline Interest in climate change & $M_{1}=5.36$ & $M_{2}=5.86$ & $Z=-2.484^{*}$ \\
\hline Concern about natural disasters & $M_{1}=5.25$ & $M_{2}=5.39$ & $Z=-0.133$ \\
\hline The use of nuclear power plants is safe & $M_{1}=3.82$ & $M_{2}=3.29$ & $t=-2.566 *$ \\
\hline Support to environmental initiatives (current vs. disposition) & $M_{1}=4.96$ & $M_{2}=5.39$ & $t=-1.968 *$ \\
\hline
\end{tabular}

* statistically significant $(p<0.05)$

\subsection{Presence, realism and involvement}

Statistically significant differences were identified in the three items dedicated to the evaluation of presence, with superior results in the immersive format compared to the online article (Table 7). In relation to which format was seen first, a comparative effect was detected that reinforces the presence values in the immersive format compared with the article when the latter was seen first.

Items related to realism (Table 7) perform better in the immersive format, while hyperrealism is low and slightly higher in relation to the article. A statistically significant difference according to format was identified when assessing the similarity of the experience in the story to the real world.

Table 7. Compared means in presence, realism, involvement and commitment

\begin{tabular}{|c|c|c|c|c|}
\hline & & $\begin{array}{c}\text { After } \\
\text { online article }\end{array}$ & $\begin{array}{c}\text { After } \\
\text { immersive format }\end{array}$ & Compared means \\
\hline \multirow{3}{*}{ Presence } & Being there & $M_{1}=3.57$ & $M_{2}=5.39$ & $t=-5.741^{* * *}$ \\
\hline & Surrounded & $M_{1}=3.36$ & $M_{2}=5.71$ & $t=-7.512^{* * *}$ \\
\hline & Present & $M_{1}=3.07$ & $M_{2}=5.14$ & $Z=-6.076^{* * *}$ \\
\hline \multirow{4}{*}{ Realism } & Represented world as real & $M_{1}=4.93$ & $M_{2}=5.46$ & $t=-1.701$ \\
\hline & Similar experience & $M_{1}=3.29$ & $M_{2}=4.29$ & $t=-3.154 * *$ \\
\hline & Hyper-realistic & $M_{1}=2.46$ & $M_{2}=2.18$ & $t=0.803$ \\
\hline & Inconsistencies & $M_{1}=4.36$ & $M_{2}=4.16$ & $Z=-0.936$ \\
\hline \multirow{4}{*}{ Involvement } & Be aware of the real world & $M_{1}=4.64$ & $M_{2}=2.82$ & $t=4.460^{* * *}$ \\
\hline & Be together & $M_{1}=3.21$ & $M_{2}=4.54$ & $Z=-3.014^{* *}$ \\
\hline & Be interacting & $M_{1}=2.18$ & $M_{2}=3.64$ & $Z=-3.173^{* *}$ \\
\hline & Whole attention & $M_{1}=4.96$ & $M_{2}=5.29$ & $t=-0.975$ \\
\hline \multirow{4}{*}{ Commitment } & Need to get informed & $M_{1}=4.96$ & $M_{2}=5.39$ & $t=-2.194 *$ \\
\hline & Need to get involved & $M_{1}=3.11$ & $M_{2}=3.25$ & $t=-0.821$ \\
\hline & Need to encourage people & $M_{1}=4.50$ & $M_{2}=5.43$ & $t=-2.956^{* *}$ \\
\hline & Need to discuss & $M_{1}=4.57$ & $M_{2}=5.00$ & $t=-1.327$ \\
\hline
\end{tabular}

* statistically significant $(p<0.05)$

$* *$ statistically significant $(p<0.01)$

$* * *$ statistically significant $(p<0.001)$ 
All items related to involvement (Table 7) performed better in the immersive format. Three variables were identified with significant differences between perception after viewing the immersive format against after reading the online article: the users felt more disconnected from what was going on around them, perceiving themselves as being next to the characters and interacting with them - although at a limited level, since the format does not provide interactive attributes.

In terms of commitment (Table 7), the users felt the need to get more information, encourage people to know about the report, get involved in an environmental initiative or organisation, and discuss the topic to a greater extent after seeing the immersive format. In the first two the difference was statistically significant compared to the data after reading the online article.

\subsection{Characterization of the experience}

Users expressed more enjoyment (Table 8) after viewing the immersive format than after reading the article online, with a statistically significant difference: they considered that the story was more captivating through the 360일.

Concerning the desire to continue the experience -a relevant indicator when evaluating narrative engagement- users indicated that they would like to continue spending time with the immersive format to a greater extent versus the online article, being a statistically significant difference. But they considered that they acquired more knowledge through reading the article versus the immersive format, being a trend difference.

Users considered the immersive format a more attractive experience due to the value of space and the feeling of presence, the technological novelty, and the narrative potential. They expressed that the immersive format provided the greatest detail and possibility of knowing the place better, as well as the feeling of being there and the closeness to the spaces and people. Being innovative drew the users' attention and awakened their interest to experiment ("I had never tried it"). Thirdly, they considered that the 360 video presented new possibilities for narration, where the stories are told by the protagonists and generating a greater connection with the story, the place and the people. As a consequence, they reported that they would recommend the immersive format above the other, and that it would have a greater impact on their memory. Lastly, $67.9 \%$ considered that the immersive format had a greater emotional effect too.

The main reason used to justify the use of the immersive format was the value of space and its protagonism. They appreciated that it is the distinguishing factor, difficult to describe in the text in such a visual way, also in the face of distant or inaccessible topics and places ("spaces where it would be impossible to physically reach"; "far from the public").

Table 8. Compared means in enjoyment, continuation desire and deepening.

\begin{tabular}{|c|c|c|c|c|}
\hline & & $\begin{array}{c}\text { After } \\
\text { online article }\end{array}$ & $\begin{array}{c}\text { After } \\
\text { immersive format }\end{array}$ & Compared means \\
\hline \multirow{3}{*}{ Enjoyment } & Enjoy the story & $M_{1}=5.57$ & $M_{2}=5.86$ & $t=-1.315$ \\
\hline & Captivating & $M_{1}=5.32$ & $M_{2}=5.86$ & $t=-2.247 *$ \\
\hline & Boring & $M_{1}=1.96$ & $M_{2}=1.75$ & $t=1.030$ \\
\hline \multirow{3}{*}{$\begin{array}{l}\text { Continuation desire and } \\
\text { deepening }\end{array}$} & Continuation desire & $M_{1}=4.00$ & $M_{2}=5.29$ & $t=-3.691 * *$ \\
\hline & Deepening & $M_{1}=5.04$ & $M_{2}=4.79$ & $t=1.126$ \\
\hline & Acquired knowledge & $M_{1}=5.00$ & $M_{2}=4.57$ & $Z=-1.775$ \\
\hline
\end{tabular}

* statistically significant $(p<0.05)$

** statistically significant $(p<0.01)$

Secondly, stories with an emotional impact or a purpose of removing the user, for example, seeking their commitment or political action, were considered appropriate for immersive formats ("Help to empathize with the situation and characters and to represent that reality in a striking way"; "Catastrophe and post-crisis stories in immersive format can be upsetting but necessary"; "Make it feel more human and touch feelings"). This was also related to ideas regarding complex realities and the social character of the stories, which were favoured by the use of the immersive format ("dealing with issues of a social nature that need to be conveyed to society urgently in order to provoke political action"; "when journalism deals with issues people don't want to see or believe").

Thirdly, the impact and visual nature of the immersive format was said to underpin its use, as well as the personification and proximity to reality that it represented ("story with lots of visual elements"; "Immersive human interest stories reaIly put the audience in someone else's shoes"; "When wanting to get closer to a subject, in the means that the user sees them and maybe also hears them").

The participants justified the use of the online article format, mainly, when there was a large volume of information and data to be transmitted to the reader. Secondly, the justifications related to the context value that could best be developed in the text ("a big context
There is no clear-cut break between 2D and $3 \mathrm{D}$ journalism; both formats are on the same continuum of emotionality and rationality 
essential to understand the story"; "When the subject is hard to grasp and it takes time to understand"). Finally, depending on the subject, politics, economics, breaking news or celebrities were topics where a text article was said to be preferable.

\subsection{Barriers}

The immersive format was considered to be attractive, but not everything about it was thought of as advantageous. The costs of the devices are still high for most $(M=5.71)$, and the risk of dizziness $(M=4.32)$ or the perception of an unrealistic position ( $M=4.46$ ) were also assessed moderately. Although these points depend largely on the product experienced, it should be noted that users identified some problems with subtitles (too long, position annoying for vision), camera position (too high, disproportions in people and spaces) and feeling dizzy. Occasionally, participants stated that the headset was uncomfortable or heavy and that the quality of the image could be improved.

Although the experiment has been conducted under laboratory conditions with control over significant variables (such as the consumption device), there are disturbing variables that may be affecting the results, as personal circumstances (previous experience with virtual reality devices, individual interest in related topics, physical and emotional condition). The analysis of perception in immersive journalism is complex and we must recognize that there are numerous factors that can affect subjects.

\section{Conclusions}

First-time media explorations in immersive journalism tend to be timid and limited, especially in terms of interactivity, with the user acting primarily as an observer (De-Bruin et al., 2020). However, this study makes it clear that the main value of immersive technologies as applied to journalism is the sense of presence, so the place takes on an indisputable protagonism, as other authors have also previously observed (Kukkakorpi; Pantti, 2020).

The comparison between the reception study and the narrative analysis allows us to understand the main affordances of each technology, although the study has limitations due to the size and characteristics of the sample that affect the extrapolation of the findings. In this case, the online article and the 360 o video form a continuum where factual information and emotional effect complement each other. The analysis of the online article shows that there are various narrative ways with which 2D online storytelling can build presence, realism and involvement. An article works well when there is a lot of information which needs to be understood and contextualized. The reception study shows clearly that the immersive format has had a great emotional effect on users. However, we cannot say that the online version does not employ immersive or emotional resources in the story or that the immersive format does not provide information they do so with different strategies following the affordances of both technologies.

The results show that immersive format provides positive effects in terms of presence, realism, involvement and commitment (H1). These are key characteristics that contribute to the sense of being there, surrounded and present in the represented place (Fukushima). Results also show that the immersive format is closer to reality, providing a similar experience to real life with a lower degree of hyperrealism, compared with the online article. The fact of being virtually at the centre of the scene is the main affordance of immersive journalism, together with the resources of an audiovisual and interactive media: choosing where to look, incorporation of audio from the field, and the invisibility and omniscience of the reporter.

We identified a significant contribution of the immersive format concerning the evolution of interests and opinions ( $\mathrm{H} 2$ ) towards nuclear energy issues. In answering the questionnaire, students from Finland and Spain reported becoming more interested in environmental issues, nuclear energy and climate change after experiencing the immersive story. Moreover, there were signs of significant changes in their opinions in relation to the risks of nuclear energy and they were also more willing to be involved in environmental initiatives in the future.

The immersive format proved to be the most attractive experience $(\mathrm{H} 3)$ due to the value of space and the feeling of presence, technological novelty and narrative potential. The desire to continue was thought to be greater in the immersive format, while more knowledge was gained from the article. The latter format allows a greater display of information and data, such as statistics or direct quotations. This means that textual narration enhances understanding, maintaining a critical distance with the issue. The information provided by the online article format may also help to process the problem, not just experience the environment. According to users, the article was preferable when there was a significant volume of information and data to take in, as well as when faced with last-minute issues, politics or economics. In contrast, a $360^{\circ}$ video features animations and stories told in the first person by protagonists. Users chose it as their preferred format when the space was the protagonist, the story had an emotional impact or if it was an especially visual issue. There are different approaches that take advantage of the characteristics of each medium, which suggests a benefit in the complementarity of the formats.
The immersive format causes a great emotional effect on users, although both formats have their strategies 
These findings also indicate that immersive storytelling can be an important part of the emotional (Beckett; Deuze, 2016) or affective turn (Wahl-Jorgensen, 2020) that is taking place in contemporary journalism. In this sense, the goal of immersive journalism to engage audiences with the news through emotions takes on value (Sánchez-Laws, 2020) in such a way that it generates involvement in what is happening. The sensation of presence and empathy towards distant and complex realities emerge as the main distinguishing values of the kind of immersive journalism that Fukushima: Contaminated lives represents.

In reference to the methodological contribution of the research, the construction of the reception study itself and the variables identified as significant illustrate important aspects to consider in future studies. However, during the execution of the experiment some aspects were also discovered, such as the importance of observing participant behaviour, asking questions before and after the viewing but not during the use of the headset, as well as taking care of the entry and exit phases of the immersive experience, also valuing the safety and comfort of the area in which it is carried out.

For future research, this study suggests the need to address reception in immersive journalism with larger and more diverse samples, under different conditions of consumption and formulating more complex analyses that allow us to know which are the decisive variables in the generation of an immersive experience. In addition, the development of immersive journalism and technological news invites to open new lines of journalism studies in the context of the metaverse.

\section{Note}

1. The reception study was first carried out at the University of Santiago de Compostela between 7 and 10 October 2019. The second part was carried out at the Tampere University between 15 October and 14 November 2019.

\section{References}

Allan, Rutger J. (2019). "Narrative immersion. Some linguistic and narratological aspects". In: Grethlein, Jonas; Huitink, Luuk; Tagliabue, Aldo (eds.). Experience, narrative, and criticism in Ancient Greece. Oxford: Oxford University Press, pp. 15-35. ISBN: 9780198848295

https://doi.org/10.1093/oso/9780198848295.003.0002

Barreda-Ángeles, Miguel (2018). “Periodismo inmersivo en España: análisis de la primera generación de contenidos periodísticos en realidad virtual". Estudios sobre el mensaje periodístico, v. 24, n. 2, pp. 1105-1120.

https://doi.org/10.5209/ESMP.62204

Beckett, Charlie; Deuze, Mark (2016). “On the role of emotion in the future of journalism”. Social media + society, v. 2 , n. 3. https://doi.org/10.1177/2056305116662395

Benítez-de-Gracia, María-José; Herrera-Damas, Susana (2018). “Inmersión del espectador en el reportaje en 360․ Análisis comparativo de ‘En la piel de un refugiado' y ‘Fukushima, vidas contaminadas'”. Doxa comunicación, n. 26, pp. 191210.

https://doi.org/10.31921/doxacom.n26a9

Berning, Nora (2011). Narrative means to journalistic ends. A narratological analysis of selected journalistic reportages. Wiesbaden: Springer VS. ISBN: 9783531926995

https://doi.org/10.1007/978-3-531-92699-5

Bird, S. Elizabeth; Dardenne, Robert-Ward (1988). "Myth, chronicle, and story - Exploring the narrative qualities of news". In: Carey, James (ed.). Media, myths, and narratives - Television and the press. Newbury Park: SAGE Publications, pp. 67-86. ISBN: 803930488

Colussi, Juliana; Reis, Thays-Assunção (2020). "Periodismo inmersivo. Análisis de la narrativa en aplicaciones de realidad virtual". Revista latina de comunicación social, v. 77, pp. 19-32.

https://doi.org/10.4185/RLCS-2020-1447

De-Bruin, Kiki; De-Haan, Yael; Kruikemeier, Sanne; Lecheler, Sophie; Goutier, Nele (2020). “A first-person promise? A content-analysis of immersive journalistic productions". Journalism, first online.

https://doi.org/10.1177/1464884920922006

De-la-Peña, Nonny; Weil, Peggy; Llobera, Joan; Giannopoulos, Elias; Pomés, Ausiàs; Spanlang, Bernhard; Friedman, Doron; Sánchez-Vives, María-Victoria; Slater, Mel (2010). "Immersive journalism: Immersive virtual reality for the first-person experience of news". Presence, v. 19, n. 4, pp. 291-301.

https://doi.org/10.1162/PRES_a_00005

Domínguez-Martín, Eva (2015). “Periodismo inmersivo o cómo la realidad virtual y el videojuego influyen en la interfaz e interactividad del relato de actualidad". El profesional de la información, v. 24, n. 4, pp. 413-423.

https://doi.org/10.3145/epi.2015.jul.08 
Domínguez-Martín, Eva (2017). “Going beyond the classic news narrative convention: The background to and challenges of immersion in journalism". Frontiers in digital humanities, v. 4.

https://doi.org/10.3389/fdigh.2017.00010

Franklin, Bob (2016). "The future of journalism. Risk, threats and opportunities". Journalism studies, v. 17, n. 7, pp. 798800.

https://doi.org/10.1080/1461670X.2016.1197641

Gynnild, Astrid; Uskali, Turo; Jones, Sarah; Sirkkunen, Esa (2020). “What is immersive journalism?”. In: Uskali, Turo; Gynnild, Astrid; Jones, Sarah; Sirkkunen, Esa (eds.). Immersive journalism as storytelling. Ethics, production, and design. Abingdon: Routledge. ISBN: 9780367713300

Jacobson, Susan; Marino, Jacqueline; Gutsche, Robert E. (2016). "The digital animation of literary journalism". Journalism, v. 17, n. 4, pp. 527-546.

https://doi.org/10.1177/1464884914568079

Jones, Sarah (2017). "Disrupting the narrative: immersive journalism in virtual reality". Journal of media practice, v. 18, n. 2-3, pp. 171-185.

https://doi.org/10.1080/14682753.2017.1374677

Kang, Seok; O’Brien, Erin; Villarreal, Arturo; Lee, Wansoo; Mahood, Chad (2019). “Immersive journalism and telepresence. Does virtual reality news use affect news credibility?”. Digital journalism, v. 7, n. 2, pp. 294-313.

https://doi.org/10.1080/21670811.2018.1504624

Kelling, Chelsea; Väätäjä, Heli; Kauhanen, Otto; Mäkelä, Ville; Ikonen, Pasi; Ronkainen, Kimmo; Keskinen, Tuuli; Sirkkunen, Esa; Uskali, Turo; Turunen, Markku (2019). “Experiences and preferences of immersive journalism: comparison of current and future media forms". In: Future of journalism conference, 12-13 October, Cardiff.

https://www.researchgate.net/publication/337772879_Experiences_and_Preferences_of_Immersive_Journalism_ Comparison_of_Current_and_Future_Media_Forms

Kukkakorpi, Mariia; Pantti, Mervi (2020). "A sense of place: VR journalism and emotional engagement". Journalism practice, v. 15, n. 6, pp. 785-802.

https://doi.org/10.1080/17512786.2020.1799237

Lecheler, Sophie (2020). "The emotional turn in journalism needs to be about audience perceptions". Digital journalism, v. 8, n. 2, pp. 287-291.

https://doi.org/10.1080/21670811.2019.1708766

Marconi, Francesco; Nakagawa, Taylor (2016). A guide for journalists in a world of immersive 3-D content. Associated Press. https://www.amic.media/media/files/file_352_1328.pdf

Neveu, Erik (2014). "Revisiting narrative journalism as one of the futures of journalism”. Journalism studies, v. 15, n. 5, pp. 533-542.

https://doi.org/10.1080/1461670X.2014.885683

Nielsen, Søren-Lund; Sheets, Penelope (2019). "Virtual hype meets reality: Users' perception of immersive journalism". Journalism, v. 22, n. 10, pp. 2637-2653.

https://doi.org/10.1177/1464884919869399

Owen, Taylor (2016). "Can journalism be virtual?". Columbia journalism review. https://www.cjr.org/the_feature/virtual_reality_facebook_second_life.php

Paíno-Ambrosio, Adriana; Rodríguez-Fidalgo, María-Isabel (2019a). "A proposal for the classification of immersive journalism genres based on the use of virtual reality and 360-degree video". Revista latina de comunicación social, v. 74, pp. 1132-1153. https://doi.org/10.4185/RLCS-2019-1375en

Paíno-Ambrosio, Adriana; Rodríguez-Fidalgo, María-Isabel (2019b). “Proposal for a new communicative model in immersive journalism". Journalism, v. 22, n. 10, pp. 2600-2617.

https://doi.org/10.1177/1464884919869710

Pavlik, John V. (2013). "Innovation and the future of journalism”. Digital journalism, v. 1, n. 2, pp. 181-193. https://doi.org/10.1080/21670811.2012.756666

Pérez-Seijo, Sara (2021). “Uso del vídeo 360 por los medios nativos digitales. Análisis exploratorio de los primeros pasos en el ecosistema periodístico español". Profesional de la información, v. 30, n. 3.

https://doi.org/10.3145/epi.2021.may.04

Pérez-Seijo, Sara; López-García, Xosé; Campos-Freire, Francisco (2018). "La aplicación de las narrativas inmersivas en los reportajes: estudio de caso del diario español 'El país'”. In: González-Esteban, José-Luis; García-Avilés, Jose-Alberto (eds.). Mediamorfosis. Radiografía de la innovación en el periodismo. Elche: SEP, pp. 61-78. ISBN: 9788494823350 
Pesonen, Emilia (2015). The user experience of digital news: Reading and authentication on browser optimized versions and digital replicas. Tampere University. https://trepo.tuni.fi/handle/123456789/22837

Ryan, Marie-Laure (2001). Narrative as virtual reality. Baltimore: The Johns Hopkins University Press.

Sahlstein, Eric; Baker, Benjamin M. A. (2017). “Narrative analysis”. In: Allen, Mike (ed.). The SAGE encyclopedia of communication research methods. Thousand Oaks: SAGE Publications, pp. 1069-1072. ISBN: 9781483381411 https://doi.org/10.4135/9781483381411.n368

Sánchez-Laws, Ana-Luisa (2020). “Can immersive journalism enhance empathy?”. Digital journalism, v. 8, n. 2, pp. $213-228$. https://doi.org/10.1080/21670811.2017.1389286

Schoenau-Fog, Henrik (2011). "Hooked! - Evaluating engagement as continuation desire in interactive narratives". In: Si, Mei; Thue, David; André, Elisabeth; Lester, James C.; Tanenbaum, Theresa-Jean; Zammitto, Veronica (eds.). ICIDS 2011: Interactive storytelling, LNCS, 7069. ISBN: 9783642252891

https://doi.org/10.1007/978-3-642-25289-1_24

Schubert, Thomas; Friedmann, Frank; Regenbrecht, Holger (2001). "The experience of presence: Factor analytic insights". Presence, v. 10, n. 3, pp. 266-281.

https://doi.org/10.1162/105474601300343603

Shin, Donghee; Biocca, Frank (2018). “Exploring immersive experience in journalism”. New media \& society, v. 20, n. 8, pp. 2800-2823.

https://doi.org/10.1177/1461444817733133

Sidorenko-Bautista, Pavel; Herranz-de-la-Casa, José-María; Molina-Díez, Marta (2020). “Evolución del periodismo inmersivo en España, desde su inicio hasta la pandemia por Covid-19”. Estudos em comunicação, n. 31, pp. 69-94. http://ojs.labcom-ifp.ubi.pt/index.php/ec/article/view/861

Sirkkunen, Esa; Uskali, Turo (2019). “Virtual reality journalism”. In: Vos, Tim P.; Hanusch, Folker (eds.). The international encyclopedia of journalism studies. Hoboken: Wiley. ISBN: 9781118841679

https://doi.org/10.1002/9781118841570.iejs0279

Sirkkunen, Esa; Vázquez-Herrero, Jorge; Uskali, Turo; Väätäjä, Heli (2020). "Exploring the immersive journalism landscape". In: Uskali, Turo; Gynnild, Astrid; Jones, Sarah; Sirkkunen, Esa (eds.). Immersive journalism as storytelling. Ethics, production, and design. Abingdon: Routledge, pp. 13-24. ISBN: 9780429437748 https://doi.org/10.4324/9780429437748-3

Slater, Mel; Usoh, Martin (1994). "Body centred interaction in immersive virtual environments". In: Magnenat-Thalmann, Nadia; Thalmann, Daniel (eds.). Artificial life and virtual reality. New York: John Wiley \& Sons, pp. 125-148. http://citeseerx.ist.psu.edu/viewdoc/summary?doi=10.1.1.109.7613

Spiller, Ralf; Maaßen, Lisa; Oehler, Michael; Hahn, David; Inderhees, Marco (2019). "Virtual reality - How public relations can make use of immersive virtual experiences. An experimental study". In: IAMCR Conference, 7-11 July, Madrid.

Steensen, Steen; Grøndahl-Larsen, Anna M.; Hågvar, Yngve-Benestad; Fonn, Birgitte-Kjos (2019). "What does digital journalism studies look like?". Digital journalism, v. 7, n. 3, pp. 320-342.

https://doi.org/10.1080/21670811.2019.1581071

Steinfeld, Nili (2020). "To be there when it happened: Immersive journalism, empathy, and opinion on sexual harassment". Journalism practice, v. 14, n. 2, pp. 240-258. https://doi.org/10.1080/17512786.2019.1704842

Sundar, S. Shyam; Kang, Jin; Oprean, Danielle (2017). "Being there in the midst of the story: How immersive journalism affects our perceptions and cognitions". Cyberpsychology, behavior, and social networking, v. 20, n. 11, pp. $672-682$. https://doi.org/10.1089/cyber.2017.0271

Ufarte-Ruiz, María-José; Calvo-Rubio, Luis-Mauricio; Murcia-Verdú, Francisco-José (2020). “Las tecnologías hi-tech en los grados en periodismo. Planes de estudios, formación de los periodistas y propuestas de inserción curricular". adComunica, n. 20, pp. 43-66.

https://www.e-revistes.uji.es/index.php/adcomunica/article/view/5384

https://doi.org/10.6035/2174-0992.2020.20.3

Uskali, Turo; Ikonen, Pasi (2021). "The impact of emotions in immersive journalism”. In: Uskali, Turo; Gynnild, Astrid; Jones, Sarah; Sirkkunen, Esa (eds.). Immersive journalism as storytelling. Ethics, production, and design. Abingdon: Routledge, pp. 49-59. ISBN: 9780429437748

https://doi.org/10.4324/9780429437748-7 
Van-Damme, Kristin; All, Anissa; De-Marez, Lieven; Van-Leuven, Sarah (2019). “360 video journalism: Experimental study on the effect of immersion on news experience and distant suffering”. Journalism studies, v. 20, n. 14, pp. $2053-2076$. https://doi.org/10.1080/1461670X.2018.1561208

Wahl-Jorgensen, Karin (2020). “An emotional turn in journalism studies?”. Digital journalism, v. 8, n. 2, pp. $175-194$. https://doi.org/10.1080/21670811.2019.1697626

Watson, Zillah (2017). VR for news: The new reality?. Reuters Institute for the Study of Journalism. https://reutersinstitute.politics.ox.ac.uk/our-research/vr-news-new-reality

Witmer, Bob G.; Singer, Michael J. (1998). "Measuring presence in virtual environments: A presence questionnaire". Presence, v. 7, n. 3, pp. 225-240. https://doi.org/10.1162/105474698565686

Wu, Huiyue; Cai, Tong; Liu, Yingxin; Luo, Dan; Zhang, Zhian (2021). “Design and development of an immersive virtual reality news application: a case study of the SARS event". Multimedia tools and applications, v. 80, n. 2, pp. 2773-2796. https://doi.org/10.1007/s11042-020-09863-w

Zelizer, Barbie (2007). “On 'having been there': 'Eyewitnessing' as a journalistic key word”. Critical studies in media communication, v. 24, n. 5, pp. 408-428.

https://doi.org/10.1080/07393180701694614

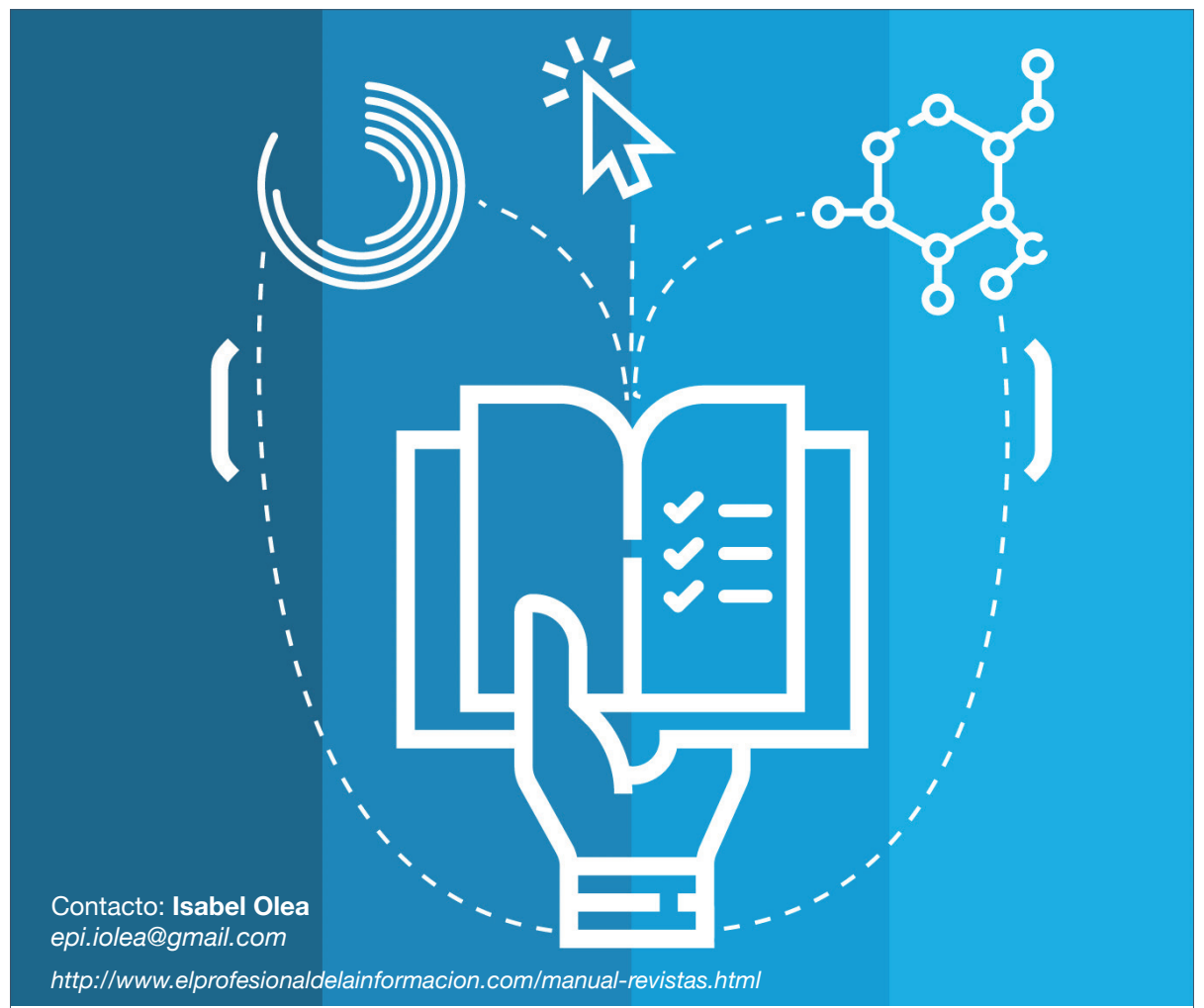

\section{Manual SCImago de revistas científicas. Creación, gestión y publicación Tomàs Baiget}

Este Manual cubre todos los factores y aspectos que un editor debe conocer para gestionar con eficacia una revista científica, desde la creación y puesta en marcha, hasta la publicación, distribución y marketing.

Algunos de los temas tratados son:

- modelos de negocio;

- acceso abierto;

- impacto e indexación en directorios, bases de datos y redes sociales;

- metadatos;

- proceso de revisión por pares (peer review);

- normas y recomendaciones de formatos;

- indicadores de calidad.

- ética;

- preservación:

- referencias bibliográficas... 